DOI (Article): https://doi.org/10.31108/2.2020.1.19.8

УДК 159.923

Клочко Алла

\title{
ОСОБЛИВОСТІ САМОРОЗВИТКУ МЕНЕДЖЕРІВ ОСВІТНІХ ОРГАНІЗАЦІЙ ТА ЙОГО ЗВ'ЯЗОК ІЗ ТРАДИЦЙНИМИ ТА ІННОВАЦІЙНИМИ СТИЛЯМИ УПРАВЛІННЯ
}

\begin{abstract}
Клочко Алла. Особливості саморозвитку менеджерів освітніх організацій та його зв'язок із традиційними та інноваційними стилями управління.

Вступ. Професійний саморозвиток відіграє важливу роль у діяльності менеджерів освіти та впливає на розвиток у них інноваційних стилів управління.

Мета дослідження: проаналізувати особливості саморозвитку менеджерів освітніх організацій та дослідити зв'язок між рівнем саморозвитку менеджерів і традиційними та інновачійними стилями управління.

Методи дослідження. Методика для вивчення бар'єрів педагогічної діяльності Т. Шамової, опитувальник «Визначення рівня емоційного інтелекту» Н. Холла.

Результати дослідження. У результаті емпіричного дослідження виявлено певні резерви щодо саморозвитку менеджерів освіти. Виділено чинники, які сприяють та перешкоджають саморозвитку менеджерів освітніх організацій. Встановлено наявність позитивного статистично значущого зв'язку між рівнями саморозвитку менеджерів освітніх організацій і традиційними і інновачійними стилями управління.
\end{abstract}

Висновки. Встановлені закономірності можуть бути використані у практичній діяльності менеджерів освіти.

Ключові слова: менеджери освітніх організацій, саморозвиток, чинники саморозвитку, традиџійні стилі управління, інноваційні стилі управління.

Клочко Алла. Особенности саморазвития менеджеров образовательных организаций и его связь с традициоными и инновационными стилями управления.

Вступление. Профессиональное саморазвитие играет важную роль в деятельности менеджеров образования и влияет на развитие у них инновационных стилей управления.

Цель. Проанализировать особенности саморазвития менеджеров образовательных организаций и изучить связь меду уровнем саморазвития менеджеров и использованием ими традиционных $u$ инновачионных стилей управления.

Методы исследования. Методика для изучения барьеров педагогической деятельности T. Шамовой, опросник «Определение уровня эмоиионального интеллекта» Н. Холла.

Результаты исследования. В результате эмпирического исследования выявлены определенные резервы в уровне саморазвития менеджеров образования. Выделены факторы, которые способствуют и препятствуют саморазвитию менеджеров образования. Установлено наличие положительной статистически значимой связи между уровнями саморазвития менеджеров образовательных организаџий и традиџионными и инноваџионными стилями управления.

Выводы. Установленные закономерности могут быть использованы в практической деятельности менеджеров образования.

Ключевые слова: образовательные организачии, саморазвитие, факторы саморазвития, типы менеджеров образовательных организаиий, инноваџионные стили управления.

Вступ. На сучасному етапі свого розвитку українське суспільство включене в потужні глобалізаційні процеси, швидко змінюються умови життя, переосмислюються ціннісні орієнтири і стратегії людського буття та професійної діяльності. Нові виклики вимагають якісного управління освітніми організаціями, що в свою чергу потребує від менеджера освіти не лише професійних знань, але й умінь швидко реагувати на зміни, що відбуваються, мотивувати педагогічний колектив до якісної самовідданої діяльності. Тому нині від професійного саморозвитку менеджерів освітніх організацій багато в чому залежить ефективність діяльності організації. 
Різні аспекти проблеми професійного саморозвитку висвітлені у наукових працях вітчизняних та зарубіжних науковців, а саме: готовність до професійного саморозвитку (Битянов, 1989; Деркач, 2006; Дурай-Новаков, 1983; Дьяченко \& Кандыбович, 1979; Максименко, Максименко \& Папуча, 2007; Бёрнс, 1989; Маралов, 2004; Маслоу, 1994; Олпорт, 2002; Роджерс, 1994; Щукина, 2015); психологічні аспекти професійного саморозвитку менеджерів освіти (Бондачук, 2008; Гаснова, 2007; Горностай, 1990; Коломінський, 2001; Фризен, 2013).

Проте, залишається не дослідженим зв'язок між саморозвитком менеджерів освіти та їх традиційними та інноваційними стилями управління, зокрема, в контексті особливостей використання емоційного інтелекту. У наших попередніх роботах (Карамушка \& Клочко, 2019; Клочко, 2019) було виділено традиційні та інноваційні стилі управління менеджерів освітніх організацій (у контексті особливостей використання ними емоційного інтелекту) та проаналізовано зв'язок між низкою характеристик менеджерів та рівнем розвитку цих стилів.

Таким чином, значущість проблеми та іï недостатня розробленість обумовили нами формулювання мети дослідження - проаналізувати особливості саморозвитку менеджерів освітніх організацій та дослідити зв'язок між рівнем саморозвитку менеджерів освіти та використання ними традиційних і інноваційних стилів управління.

\section{Завдання дослідження:}

1. Визначити рівень саморозвитку менеджерів освітніх організацій.

2. Дослідити чинники, як сприяють та перешкоджають саморозвитку менеджерів освітніх організацій.

3. Проаналізувати зв'язок між рівнем саморозвитку менеджерів освіти та використання ними традиційних і інноваційних стилів управління.

Методи та організація дослідження. Для вивчення рівнів саморозвитку менеджерів освіти та чинників, що стимулюють і перешкоджають саморозвитку, використовувалася методика вивчення бар'єрів педагогічної діяльності (Шамова, 1992). Методика дає можливість виявити такі рівні саморозвитку, як: високий (активний розвиток); середній (відсутня стала система саморозвитку); низький (розвиток, який зупинився). Методика також дозволяє виявити дві групи чинників, що стимулюють саморозвиток і перешкоджають йому. До чинників, які сприяють саморозвитку, належать: інтерес до роботи; заняття самоосвітою; навчання на курсах; методична робота; довіра; новизна діяльності, умови роботи і можливість експериментування; організація праці в закладі освіти; приклад і вплив керівників; приклад і вплив колег; зростаюча відповідальність, можливість отримати визнання у колективі. Серед чинників, які перешкоджають саморозвитку, виділяють такі: стан здоров'я; недостатня кількість часу; обмежені ресурси; власна інерція; відсутність підтримки і допомоги з боку керівництва; неадекватний зворотний зв'язок з членами колективу й керівниками; ворожість оточуючих, які погано сприймають зміни, розчарування внаслідок попередніх невдач.

На основі методики «Визначення рівня емоційного інтелекту» (Н. Холл) (Фетискин \& Козлов \& Мануйлов, 2002) нами було визначено традиційні та інноваційні типи менеджерів освітніх організацій (у контексті розвитку в них емоційного інтелекту).

Статистична обробка даних здійснювалась за допомогою пакета статистичних програм SSPS (версія 22). Використовувалась описова статистика та кореляційний аналіз.

Вибірка дослідження. Дослідження було проведене у 2018 році в освітніх організаціях Житомирської, Київської, Львівської, Луцької та Чернігівської областей. Дослідженням було охоплено 1219 менеджерів освітніх організацій.

За віковим складом учасники опитування були розподілені наступним чином: до 30 років - 9,7\%, від 31 до 40 років - 23,9\%, від 41 до 50 років - 32,8\%, від 50 років - 22,3\%. Серед опитаних менеджерів було 3,8\% чоловіків та 93,4\% жінок. Щодо сімейного стану, то опитані утворили такі групи: неодружені (незаміжні) - 27,9\%, одружені (заміжні) - 71,7\%. У 78,8\% опитаних є діти, в 21,2\% дітей немає.

В освітніх організаціях опитані займали такі посади: заступник керівника закладу освіти - 74,3\%, керівники - 25,7\%. Опитані мають наступний рівень освіти: загальну середню та 
середню спеціальну освіту - 6,8\%, вищу - 92,0\%. Щодо типу освіти учасники розділилися наступним чином: гуманітарна $-59,6 \%$, юридично-економічна $-3,1 \%$, технічно-природнича $18,5 \%$. Загальний трудовий стаж у менеджерів складає: до 15 років - 24,8\%, від 16 до 25 років $28,1 \%$, від 26 до 35 років - 30,2\%, понад 35 років - 30,2\%. За стажем роботи на посаді опитані розподілилися наступним чином: до 5 років - 16,5\%, від 6 до 15 років - 20,2\%, від 16 до 25 років - 23,5\%, понад 25 років - 39,9\%. За кваліфікаційними категоріями учасники розподілилися на групи: спеціаліст - 19,3\%, спеціалісти I та II категорії - 19,6\%, спеціаліст вищої категорії - 59,3\%. 46,2\% опитаних мають педагогічне звання «вчитель-методист». За наявністю відзнак 35,2\% опитаних мають відзнаки МОН України, 64,6\% - інші відзнаки.

Результати дослідження. Проаналізуємо результати дослідження, які стосуються рівнів саморозвитку менеджерів освіти (рис. 1).

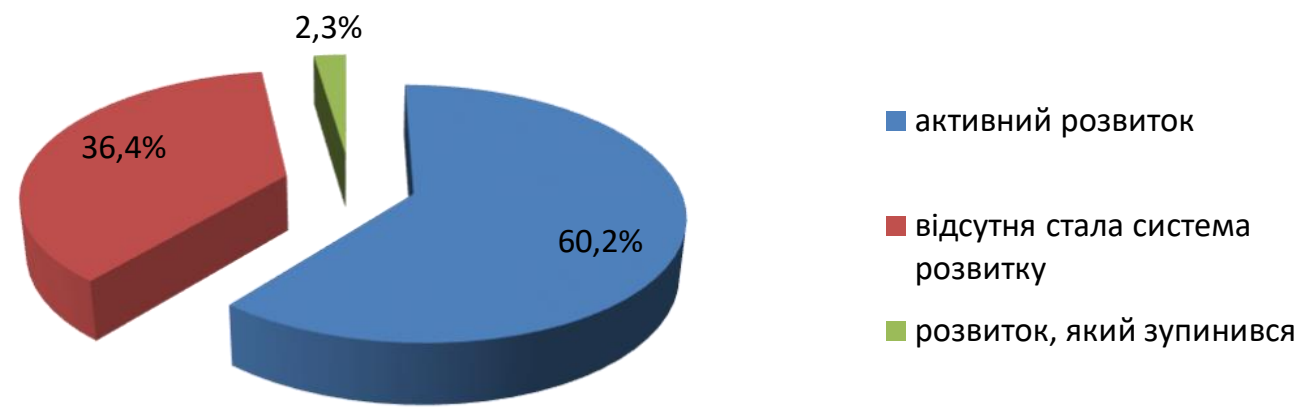

\section{Рис. 1. Рівні саморозвитку у менеджерів освітніх організацій (у \% від загальної кількості опитаних)}

Так, 3 даних рис. 1 видно, що найбільша група опитаних менеджерів освіти (60,2\%) перебуває на високому рівні саморозвитку (активному розвитку). Середній рівень (відсутність сталої системи розвитку) зафіксовано у $36,4 \%$ респондентів. Низький рівень (розвиток, який зупинився) виявлено у 2,3\% .

Це свідчить про те, що для значної кількості менеджерів характерний високий рівень саморозвитку, що можна пояснити, скоріше за все, специфікою діяльності менеджерів освіти, яка спрямована на створення в освітньому закладі повноцінних умов для навчання, виховання та розвитку особистості, а також тим фактом, що постійні зміни в соціальному середовищі детермінують необхідність постійного розвитку освітньої організації, управління нею, становлення менеджера освіти нового типу. Разом із тим, отримані дані свідчать і про те, що в певної частини менеджерів освіти є резерви для оптимізації свого саморозвитку.

Далі проаналізуємо чинники, що сприяють саморозвитку менеджерів освітніх організацій.

Як видно із табл. 1, до першої групи (за змістом чинників та кількістю однозначно позитивних відповідей «так») можна віднести такі чинники: інтерес до роботи $(48,6 \%)$; заняття самоосвітою $(45,9 \%)$; навчання на курсах $(42,6 \%)$; методична робота $(41,4 \%)$. Як бачимо, ця група чинників має стосується наявності в менеджерів освіти позитивної мотиваиії до своєї роботи та використанням різних форм підвищення кваліфікащї та вдосконалення.

Серед позитивних чинників, які належать до другої групи чинників, і чий вплив є дещо меншим, є: новизна діяльності; умови роботи і можливість експериментування $(37,1 \%)$; організація праці в закладі $(34,4 \%)$. Тобто дана група чинників стосується впровадження інновачійного змісту діяльності та забезпечення сприятливих умов прачі в освітньому закладі.

I третя група чинників пов'язана 3 партнерською взаємодією 3 керівництвом та педагогічним колективом: довіра до інших (38,7\%); приклад і вплив керівників (33,2\%); приклад і вплив колег (32,7\%); увага до цієї проблеми керівників (32,3\%); зростаюча відповідальність (29,9\%); можливість отримати визнання у колективі $(29,4 \%)$. 
Чинники, які сприяють саморозвитку менеджерів освітніх організацій (у \% від загальної кількості опитаних)

\begin{tabular}{|c|c|c|c|c|c|}
\hline \multirow[b]{2}{*}{ Чинники } & \multicolumn{5}{|c|}{ Рівні стимулювання } \\
\hline & ні & швидше ні & і так, і ні & швидше так & так \\
\hline Інтерес до роботи & 7,2 & 5,3 & 11,6 & 27,2 & 48,6 \\
\hline Заняття самоосвітою & 6,8 & 4,7 & 13,9 & 28,7 & 45,9 \\
\hline Навчання на курсах & 7,7 & 6,2 & 14,8 & 28,8 & 42,6 \\
\hline Методична робота & 8,4 & 5,9 & 16,9 & 27,3 & 41,4 \\
\hline Довіра & 6,7 & 6,2 & 19,3 & 29,2 & 38,7 \\
\hline $\begin{array}{lcr}\text { Новизна діяльності, умови } \\
\text { роботи } \\
\text { експериментування }\end{array}$ & 6,7 & 7,4 & 17,8 & 31,0 & 37,1 \\
\hline Організація праці в закладі & 8,9 & 5,9 & 18,1 & 32,7 & 34,4 \\
\hline Приклад і вплив керівників & 5,6 & 11,0 & 18,9 & 31,3 & 33,2 \\
\hline Приклад і вплив колег & 6,8 & 8,5 & 21,8 & 30,1 & 32,7 \\
\hline $\begin{array}{llll}\text { Увага до цієї } \\
\text { керівництва }\end{array}$ & 7,4 & 8,0 & 18,1 & 34,2 & 32,3 \\
\hline Зростаюча відповідальність & 6,1 & 7,5 & 21,4 & 35,2 & 29,9 \\
\hline $\begin{array}{l}\text { Можливість отримати } \\
\text { визнання у колективі }\end{array}$ & 5,6 & 10,3 & 24,1 & 30,7 & 29,4 \\
\hline
\end{tabular}

Таким чином, результати дослідження свідчать про те, що основні чинники, які сприяють саморозвитку менеджерів освітніх організацій, утворюють три основні групи і стосуються позитивної мотивації до своєї роботи та використанням різних форм підвищення кваліфікації та вдосконалення; впровадження інноваційного змісту діяльності та забезпечення сприятливих умов праці в освітньому закладі; партнерської взаємодії 3 керівництвом та педагогічним колективом.

Отже, створення в освітніх організаціях організаційно-психологічних умов, які можуть враховувати дію цих чинників, сприятиме підвищенню рівня саморозвитку менеджерів освітніх організацій. Мова йде про актуалізацію у менеджерів інтересу до роботи (зокрема, на основі використання позитивних прикладів колег щодо нововведень в освітніх закладах та їх позитивних результатів), організація різних сучасних форм підвищення кваліфікації, у тому числі і дистанційних, впровадження креативного підходу у вирішенні управлінських завдань, партнерських норм взаємодії з колегами (створення команд для вирішення різних освітніх завдань, надання підтримки один одному та ін.).

Тепер висвітлимо чинники, що перешкоджають саморозвитку менеджерів освітніх організацій.

Як видно із табл. 2, до першої групи чинників (за змістом чинників та кількістю однозначно позитивних відповідей «так») було віднесено такі чинники: стан здоров'я (23,5\%); недостатня кількість часу (22,1\%); обмежені ресурси $(18,7 \%)$; власна інерція $(17,6 \%)$; розчарування внаслідок попередніх невдач (12,9\%). Можна говорити про те, що ця група чинників пов'язана 3 недостатньою організаџією менеджерами освіти власної життедіяльності.

Другу групу утворили такі чинники: відсутність підтримки i допомоги 3 боку керівництва $(14,1 \%)$; ворожість оточуючих $(13,7 \%)$; неадекватний зворотний зв'язок із членами колективу й керівниками $(12,6 \%)$. Тобто дана група стосується негативної взаємодіi менеджерів освіти з професійним оточенням. 
Таблиия 2

Чинники, які перешкоджають саморозвитку менеджерів освітніх організацій (у \% від загальної кількості опитаних)

\begin{tabular}{|l|c|c|c|c|c|}
\hline \multirow{2}{*}{ Чинники } & \multicolumn{5}{|c|}{ Рівні перешкод } \\
\cline { 2 - 6 } & ні & швидше ні & і так, і ні & швидше так & так \\
\hline Стан здоров’я & 11,6 & 14,7 & 29,7 & 20,5 & 23,5 \\
\hline Недостатня кількість часу & 8,4 & 13,2 & 30,8 & 25,5 & 22,1 \\
\hline Обмежені ресурси & 13,1 & 14,4 & 29,9 & 23,9 & 18,7 \\
\hline Власна інерція & 14,2 & 12,6 & 36,2 & 19,4 & 17,6 \\
\hline $\begin{array}{l}\text { Відсутність підтримки і допомоги 3 } \\
\text { боку керівництва }\end{array}$ & 16,2 & 15,5 & 28,1 & 26,2 & 14,1 \\
\hline $\begin{array}{l}\text { Ворожість оточуючих, які погано } \\
\text { сприймають зміни }\end{array}$ & 18,0 & 20,9 & 27,6 & 19,8 & 13,7 \\
\hline $\begin{array}{l}\text { Розчарування внаслідок попередніх } \\
\text { невдач }\end{array}$ & 12,1 & 20,8 & 34,2 & 20,0 & 12,9 \\
\hline $\begin{array}{l}\text { Неадекватний зворотний зв'язок 3 } \\
\text { членами колективу й керівниками }\end{array}$ & 18,0 & 18,2 & 26,7 & 24,4 & 12,6 \\
\hline
\end{tabular}

Отже, отримані дані свідчать про те, що основні чинники, які перешкоджають саморозвитку менеджерів освітніх організацій, належать до двох основних груп: недостатня організація менеджерами власної життєдіяльності; негативна взаємодія менеджерів із професійним оточенням.

Таким чином, створення в освітніх організаціях організаційно-психологічних умов, які можуть «нейтралізувати» дію цих чинників, може сприяти підвищенню рівня саморозвитку менеджерів освітніх організацій. Мова йде про профілактику перевантаження та можливого професійного вигорання менеджерів освіти, оволодіння ними навичками тайм-менеджменту, врахування переваг та обмежень у власній управлінській діяльності, формування сприятливого соціально-психологічного клімату в колективі та ін.

Далі проаналізуємо зв'язок рівня саморозвитку та традиційних і інноваційних стилів управління менеджерів освітніх організацій.

Зазначимо, що в попередніх наших роботах (Карамушка \& Клочко, 2019) було виділено три типи менеджерів освітніх організацій за емоційним інтелектом: «Емоційно необізнаний», «Контролюючий емоції», «Емоційно чутливий», та зроблено висновок про те, що менеджери, які належать до типів «Контролюючий емоції» та «Емоційно чутливий», використовують інноваційні стилі управління, а менеджери, які належать до типу «Емоційно необізнаний», застосовують традиційні стилі управління.

Результати проведеного кореляційного аналізу свідчать, що існує позитивний зв'язок статистично значущий зв'язок $(\mathrm{p}<0,001)$ між рівнем саморозвитку менеджерів освітніх організацій та використання ними традиційних та інноваційних стилів управління (табл. 3).

Сутність виявленого зв'язку полягає в тому, що в міру підвищення рівня саморозвитку зростає кількість менеджерів освіти, які використовують інноваційні стилі управління. Про це свідчать такі дані.

Так, серед менеджерів, які мають високий рівень саморозвитку, кількість осіб, яким притаманні традиційні стилі управління (відносяться до типу «Емоційно необізнаний»), складає $46,0 \%$, в той час як серед менеджерів, для яких характерні інноваційні стилі (належать до типів «Контролюючий емоції» та «Емоційно чутливий»), кількість таких осіб в півтора раза більше відповідно 71,9\% та 70,3\%. 


\section{Зв'язок між рівнем саморозвитку менеджерів освітніх організацій та традиційними і інноваційними стилями управління (у \% від загальної кількості опитаних)}

\begin{tabular}{|c|c|c|c|}
\hline \multirow{2}{*}{$\begin{array}{c}\text { Рівні саморозвитку } \\
\text { розвитку }\end{array}$} & \multicolumn{3}{|c|}{ Типи менеджерів освітніх організацій } \\
\hline & $\begin{array}{c}\text { «Емоційно } \\
\text { необізнаний» } \\
\text { (використовують } \\
\text { традиційні стилі } \\
\text { управління) }\end{array}$ & $\begin{array}{c}\text { «онтролюючий } \\
\text { емоції» } \\
\text { (використовують } \\
\text { інноваційні стилі } \\
\text { управління) }\end{array}$ & $\begin{array}{c}\text { «Еоційно чутливий» } \\
\text { (використовують } \\
\text { інноваційні стилі } \\
\text { управління) }\end{array}$ \\
\hline $\begin{array}{c}\text { Високий рівень } \\
\text { саморозвитку } \\
\text { (активний розвиток) }\end{array}$ & $46,0 * * *$ & $71,9 * * *$ & $70,3 * * *$ \\
\hline $\begin{array}{c}\text { Середній рівень саморозвитку } \\
\text { (відсутня стала система } \\
\text { саморозвитку) }\end{array}$ & $50,9 * * *$ & $26,1 * * *$ & $27,9 * * *$ \\
\hline $\begin{array}{c}\text { Низький рівень } \\
\text { саморозвитку } \\
\text { (розвиток, який зупинився) }\end{array}$ & $3,1 * * *$ & $2,0 * * *$ & $1,9 * * *$ \\
\hline
\end{tabular}

I протилежна картина спостерігається щодо середнього рівня саморозвитку. Серед менеджерів, у яких виявлено середній рівень саморозвитку, кількість осіб, які використовують традиційні стилі управління (належать до типу «Емоційно необізнаний»), складає 50,9\%, в той час як серед менеджерів, які застосовують інноваційні стилі (належать до типів «Контролюючий емоції» та «Емоційно чутливий»), кількість таких осіб майже вдвічі менша відповідно 26,1\% та 27,9\%.

I насамкінець, така сама закономірність виявлена і стосовно низького рівня саморозвитку менеджерів. Серед менеджерів, у яких виявлено низький рівень саморозвитку, кількість осіб, які використовують традиційні стилі управління (належать до типу «Емоційно необізнаний»), складає $3,1 \%$, в той час як серед менеджерів, які орієнтовані на інноваційні стилі (належать до типів «Контролюючий емоції» та «Емоційно чутливий»), кількість таких осіб майже вдвічі менша - відповідно 2,0\% та 1,9\%.

Отже, можна говорити про те, що результати дослідження показали зв'язок саморозвитку та кількісної представленості менеджерів освітніх організацій, які використовують інноваційні стилі управління. Усе це свідчить про необхідність посилення рівня саморозвитку менеджерів освіти, оскільки його професійна діяльність постійно ускладнюється і трансформується до вимог сучасної освітньої галузі. Тому менеджер покликаний гнучко реагувати на виклики часу, бути професійно мобільним, володіти комплексом соціальних, професійних, особистісних компетентностей, які забезпечать його професійний саморозвиток.

\section{Висновки:}

1. У результаті емпіричного дослідження виявлено певні резерви щодо саморозвитку менеджерів освіти.

2. Виділено чинники, які сприяють саморозвитку менеджерів освітніх організацій: позитивна мотивація до своєї роботи та використання різних форм підвищення кваліфікації та вдосконалення; впровадження інноваційного змісту діяльності та забезпечення сприятливих умов праці в освітньому закладі; реалізація партнерської взаємодії 3 керівництвом та педагогічним колективом. 
3. Обгрунтовано чинники, які перешкоджають саморозвитку менеджерів освітніх організацій: недостатня організація менеджерами власної життєдіяльності; негативна взаємодія менеджерів з професійним оточенням.

4. Встановлено наявність позитивного статистично значущого зв'язку між рівнями саморозвитку менеджерів освітніх організацій і традиційними і інноваційними стилями управління (у міру підвищення рівня саморозвитку зростає кількість менеджерів освіти, які використовують інноваційні стилі управління).

5. Отримані дані можуть бути використані менеджерами освітніх організацій з метою оптимізації саморозвитку менеджерів освітніх організацій та використання ними інноваційних стилів управління (у контексті розвитку емоційного інтелекту).

Перспективи подальших досліджень вбачаємо у дослідженні можливостей створення психологічних умов саморозвитку менеджерів освітніх організацій та підготовці тренінгової програми, яка сприятиме активізації розвитку зазначених процесів.

\section{Лiтература}

1. Бёрнс, Р. Б. (1989). Я-конщепция и воспитание. Москва.

2. Битянова, Н. Р. (1989). Проблема саморазвития личности в психологии: аналитический обзор. Москва.

3. Бондарчук, О. I. (2008). Соціально-психологічні основи особистісного розвитку керівників загальноосвітніх навчальних закладів у професійній діяльності. Київ.

4. Гасанова, П. Г. (2007). Профессиональное саморазвитие личности в современных психологических учениях. Педагогическое образование и наука, 3, 35-36.

5. Горностай, П. П. (1990). Готовность личности к саморазвитию как психологическая проблема. Луцк.

6. Деркач, А. А., \& Селезнева, Е. В. (2006). Акмеологическая культура личности: содержание, закономерности, механизмы развития. Воронеж: НПО «МОДЭК».

7. Дурай-Новакова, К. М. (1983). Формирование профессиональной готовности студентов к педагогической деятельности. Автореф. дисс. д-ра пед. наук. Москва.

8. Дьяченко, М. И., \& Кандыбович, Л. А. (1979). Педагогические проблемы готовности к деятельности. Минск.

9. Карамушка, Л. М., \& Клочко, А. О. (2019) Інноваційні стилі управління менеджерів освітніх організацій у контексті розвитку емоційного інтелекту: зв'язок 3 психологічними та організаційно-функціональними характеристиками організації. Організаційна психологія. Економічна психологія, 2-3 (17), 47-57.

10. Клочко, А. О. (2019). Розвиток емоційного інтелекту у менеджерів освітніх організацій: зв'язок із соціальнодемографічними та організаційно-професійними чинниками. Організаційна психологія. Економічна психологія, 1 (16), 54-63.

11. Коломінський, Н. Л. (2001). Психологія менеджменту в освіті (соиіально-психологічний аспект). Київ.

12. Максименко, С. Д., Максименко, К. С., \& Папуча, М. В. (2007). Психологія особистості. Київ: ТОВ «КММ».

13. Маралов, В. Г. (2004). Основы самопознания и саморазвития. Москва: Издат. центр «Академия».

14. Маслоу, А. (1994). Самоактуализация личности и образование. Киев- Донецк : Ин-т психологии.

15. Олпорт, Г. (2002). Становление личности: избранные труды. Москва: Смысл.

16. Роджерс, К. Р. (1994). Взгляд на психотерапию. Становление человека. Москва: Изд. группа «Прогресс»; Универс.

17. Фетискин, Н. П., Козлов, В. В., \& Мануйлов, Г. М. (2002). Социально-психологическая диагностика развития личности и малых групп. Москва: Изд-во Института Психотерапии.

18. Фризен, М. А. (2013). Психология саморазвития. Петропавловск-Камчатский: КамГУ им. Витуса Беринга.

19. Шамова, Т. М. (1992). Менеджмент в управлінні школою. Москва: NB-Магистр.

20. Щукина, М. А. (2015). Психология саморазвития личности: субъектный подход. Дисс. д-ра психол. наук. СанктПетербург, 2015.

\section{References}

1. Biorns, R. B. (1989). Ja-koncepcija i vospitanie [Self-concept and education]. Moskva [in Russian].

2. Bitjanova, N. R. (1989). Problema samorazvitija lichnosti v psihologii: analiticheskij obzor [The problem of personal self-development in psychology: an analytical review]. Moskva [in Russian].

3. Bondarchuk, O. I. (2008). Sotsialno-psykholohichni osnovy osobystisnoho rozvytku kerivnykiv zahalnoosvitnikh navchalnykh zakladiv u profesiinii diialnosti [Social and psychological foundations of personal development of comprehensive school principals in their professional activity]. Kyiv [in Ukrainian].

4. Gasanova, P. G. (2007). Professional'noe samorazvitie lichnosti v sovremennyh psihologicheskih uchenijah [Professional self-development of an individual in modern psychological teachings]. Pedagogicheskoe obrazovanie $i$ nauka, 3, 35-36 [in Russian].

5. Gornostaj, P. P. (1990). Gotovnost' lichnosti k samorazvitiju kak psihologicheskaja problema [An individual's readiness for self-development as a psychological problem]. Lutsk [in Russian]. 
6. Derkach, A. A., \& Selezneva, E. V. (2006). Akmeologicheskaja kul'tura lichnosti: soderzhanie, zakonomernosti, mehanizmy razvitija [Personal acmeological culture: content, patterns, development mechanisms]. Voronezh: NPO «MODEK» [in Russian].

7. Duraj-Novakova, K. M. (1983). Formirovanie professional'noj gotovnosti studentov k pedagogicheskoj dejatel'nosti [Formation of students' professional readiness for teaching]. Extended abstract of Doctor's thesis. Moskva [in Russian].

8. D'jachenko, M. I., \& Kandybovich, L. A. (1979). Pedagogicheskie problemy gotovnosti $k$ dejatel'nosti [Educational problems of readiness for work]. Minsk [in Russian].

9. Karamushka, L. M., \& Klochko, A. O. (2019) Innovatsiini styli upravlinnia menedzheriv osvitnikh orhanizatsii u konteksti rozvytku emotsiinoho intelektu: zviazok $\mathrm{z}$ psykholohichnymy ta orhanizatsiino-funktsionalnymy kharakterystykamy orhanizatsii [Educational organization innovation management styles in the context of development of emotional intelligence: relationship with psychological and functional characteristics of the organization]. Orhanizatsiina psykholohiia. Ekonomichna psykholohiia, 2-3 (17), 47-57 [in Ukrainian].

10. Klochko, A. O. (2019). Rozvytok emotsiinoho intelektu u menedzheriv osvitnikh orhanizatsii: zviazok iz sotsialnodemohrafichnymy ta orhanizatsiino-profesiinymy chynnykamy [Development of educational organization heads' emotional intelligence: relationship with social, demographic, organizational and professional factors]. Orhanizatsiina psykholohiia. Ekonomichna psykholohiia, 1 (16), 54-63 [in Ukrainian].

11. Kolominskyi, N. L. (2001). Psykholohiia menedzhmentu v osviti (sotsialno-psykholohichnyi aspekt) [Management psychology in education (a social-psychological aspect)]. Kyiv [in Ukrainian].

12. Maksymenko, S. D., Maksymenko, K. S., \& Papucha, M. V. (2007). Psykholohiia osobystosti [Personality psychology]. Kyiv: TOV «KMM».

13. Maralov, V. G. (2004). Osnovy samopoznanija i samorazvitija [Fundamentals of self-knowledge and selfdevelopment]. Moskva: Izdat. centr «Akademija»[in Russian].

14. Maslou, A. (1994). Samoaktualizacija lichnosti i obrazovanie [Self-actualization and education]. Kiev-Doneck: In-t psihologii [in Russian].

15. Olport, G. (2002). Stanovlenie lichnosti: izbrannye trudy [Becoming personality: selected works]. Moskva: Smysl [in Russian].

16. Rodzhers, K. R. (1994). Vzgljad na psihoterapiju. Stanovlenie cheloveka [A look at psychotherapy. The formation of man]. Moskva: Izd. gruppa «Progress»; Univers [in Russian].

17. Fetiskin, N. P., Kozlov, V. V., \& Manujlov, G. M. (2002). Social'no-psihologicheskaja diagnostika razvitija lichnosti $i$ malyh grupp [Socio-psychological assessment of personality and a small group development]. Moskva: Izd-vo Instituta Psihoterapii [in Russian].

18. Frizen, M. A. (2013). Psihologija samorazvitija [Psychology of self-development]. Petropavlovsk-Kamchatskij: KamGU im. Vitusa Beringa [in Russian].

19. Shamova, T. M. (1992). Menedzhment $v$ upravlinni shkoloiu [School management]. Moskva: NB-Mahistr [in Ukrainian].

20. Shhukina, M. A. (2015). Psihologija samorazvitija lichnosti: subiektnyj podhod [Psychology of personal selfdevelopment: a subjective approach]. Doctor's thesis. Sankt-Peterburg, 2015 [in Russian].

\section{Klochko, Alla. Self-development of managers of educational organizations and its relationship with traditional and innovative management styles. \\ Introduction. Professional self-development plays an important role in the work of education managers} and promotes the development of their innovative management styles.

Aim of the study: To analyze some aspects of educational organization managers' self-development and the relationship between the levels of educational organization managers' self-development and their use of traditional and innovative management styles.

Research methods. T. Shamova Educational Activity Barriers questionnaire, N. Hall Determining the Level of Emotional Intelligence, descriptive statistics and correlation analysis.

Research results. The empirical study found some potentials for education managers' self-development and the factors that contribute to it, which included positive work motivation and use of various forms of professional development, promotion of innovative activities and creation of favorable working conditions in an educational institution, as well as partnership interaction between the educational institution management and teaching staff. Among the factors that impede educational organization managers' self-development the author discusses education managers' poorly organized personal life and their negative interaction with their professional environment. There was a positive statistically significant relationship between the levels of educational organization managers' self-development and their use of traditional and innovative management styles (as the level of education managers' self-development increased, their preference of innovative management styles increased, too).

Keywords: managers of educational organizations, self-development, self-development factors, traditional management styles, innovative management styles. 


\title{
Відомості про автора
}

Клочко Алла Олексіївна, кандидат педагогічних наук, доцент, доцент кафедри педагогіки, психології та менеджменту Білоцерківського інституту неперервної професійної освіти Державного закладу вищої освіти «Університет менеджменту освіти», м. Біла Церква, Україна.

Klochko, Alla Oleksiyivna, $\mathrm{PhD}$, associate professor, associate professor of the department of pedagogy, psychology and management Bilotserkivskiy Institute of continuous professional education State Higher Educational Institution «University of Educational Management», Bila Tserkva, Ukraine.

E-mail: klochko_alla@ukr.net

ORCID ID: https://orcid.org/0000-0001-6631-2638

Отримано 26 грудня 2019 р.

Рецензовано 20 січня 2020 p.

Прийнято 28 січня 2020 p.

DOI (Article): https://doi.org/10.31108/2.2020.1.19.9

УДК 159.9

\section{Кудринська Галина}

\section{ОСОБЛИВОСТІ СПРИЙМАННЯ ВЛАСНОЇ ПРОФЕСІЙНОЇ ДІЯЛЬНОСТІ ПРАЦІВНИКАМИ СЛУЖБ УПРАВЛІННЯ ПЕРСОНАЛОМ ДЕРЖАВНИХ ОРГАНІВ}

\author{
Кудринська Галина. Особливості сприймання власної професійної діяльності працівниками \\ служб управління персоналом державних органів. \\ Вступ. Трансформаційні процеси формують у професійній свідомості працівників зміну уявлень
} та ставлення до своєї професійної діяльності.

Мета дослідження: аналіз особливостей сприйняття власної професійної діяльності прачівниками служб управління персоналом центральних органів виконавчої влади.

Методи. Для досягнення мети використано метод семантичного диференціалу, анкетування та психодіагностичні методики.

Результати дослідження. Розкрито психосемантичні особливості сприймання професійної діяльності, зокрема, здійснено опис семантичного простору та шляхом кластерного аналізу виокремлено два полярні типи сприймання професійної діяльності.

Висновки. Виділено два типи сприйняття працівниками служб управління персоналом власної професійної діяльності: позитивний та негативний.

Ключові слова: сприйняття професійної діяльності, образ професії, психосемантика професії, служба управління персоналом, державний орган, державна служба, семантичний диференціал, ставлення до професійної діяльності, управління персоналом.

Кудринская Галина. Особенности восприятия собственной профессиональной деятельности работниками служб управления персоналом государственных органов.

Введение. Трансформачионные прочессы формируют в профессиональном сознании работников смену представлений и отношения к своей профессиональной деятельности.

Цель исследования: анализ особенностей восприятия собственной профессиональной деятельности работниками служб управления персоналом иентральных органов исполнительной власти.

Методы. Для достижения иели использован метод семантического дифференииала, анкетирование и психодиагностические методики.

Результаты исследования. Раскрыты психосемантические особенности восприятия профессиональной деятельности, в частности, осуществлено описание семантического пространства и путем кластерного анализа выделены два полярных типа восприятия профессиональной деятельности. 